\title{
SHORT REPORT: REQUIREMENT OF B CELLS FOR DELAYED TYPE HYPERSENSITIVITY-LIKE PATHOLOGY AFTER SECONDARY INFECTION WITH LEISHMANIA MAJOR IN RESISTANT C57BL/6 MICE
}

\author{
GREGORY K. DEKREY, JEREMY J. JONES, M. LAMINE MBOW, CLAUDIA I. BRODSKYN, AND RICHARD G. TITUS \\ Department of Biological Sciences, University of Northern Colorado, Greeley, Colorado; Department of Pathology, Colorado State \\ University, Fort Collins, Colorado; Centocor, Incorporated, Infectious Diseases, Malvern, Pennsylvania; Centro de Pesquisa Gonçalo
} Moniz-FIOCRUZ/Bahia, Salvador, Bahia, Brazil

\begin{abstract}
B cell-deficient C57Bl/6 ( $\mu \mathrm{MT})$ mice were resistant to Leishmania major after both primary and secondary parasite challenge. However, unlike in wild-type mice, secondary infection in $\mu$ MT mice was not accompanied by a marked delayed type hypersensitivity-like response, and interferon- $\gamma$ (IFN- $\gamma$ ) levels were approximately half of those in wild-type mice. These results suggest that B cells are involved in IFN- $\gamma$ production and the pathology of secondary infection.
\end{abstract}

Leishmania major is an obligate intracellular parasite that induces cutaneous lesions in humans and animals. Most laboratory mice are resistant to primary infection with $L$. major because they develop protective T helper type 1 (Th1) immune responses. Unlike the essential role for $\mathrm{T}$ cells in this resistance, the role of $\mathrm{B}$ cells in primary resistance to $L$. major appears to be minimal. ${ }^{1-5}$ Although one study has shown that depletion of B cells in normally $L$. major-resistant mice results in a lack of resistance, ${ }^{6}$ three other studies found the opposite result: resistance to $L$. major infection developed normally in C57Bl/6-Igh- $6^{\text {tmICgn }}$ ( $\left.\mu \mathrm{MT}\right)$ mice, which lack mature B cells, ${ }^{7}$ and in mice depleted of either B cells or B-1 cells using anti- $\mu$ antibody or radiation treatment, respectively. ${ }^{8,9}$ In addition to these studies, the finding that primary resistance does not require antibodies to $L$. major supports the minimal role conclusion for B cells. ${ }^{2,10,11}$

Recent studies have shown that the importance of B cells in primary and secondary responses to intracellular pathogens can differ. In both wild-type and $\mu \mathrm{MT}$ mice, primary infection with the intracellular bacterial parasite Chlamydia tracomatis leads to immunologic resistance. ${ }^{12,13}$ However, in contrast to wild-type mice, resistance to a secondary challenge is reduced or absent in $\mu$ MT mice. ${ }^{12,13}$ Interestingly, both interferon- $\gamma$ (IFN- $\gamma$ ) production and delayed type hypersensitivity (DTH) responses are also reduced following secondary challenge in $\mu \mathrm{MT}$ mice. ${ }^{13}$ Reduction of IFN- $\gamma$ production in B celldeficient mice, relative to wild-type mice, has also been reported following infection with Listeria monocytogenes or Neospora caninum. ${ }^{14,15}$ Both DTH responses and IFN- $\gamma$ production are closely associated with resistance to L. major, and the development of Th1 responses correlates with the ability to develop DTH responses to Leishmania antigens. ${ }^{3,4,9,16,17}$ Although it is evident that the absence of B cells does not alter resistance to L. major following primary infection, ${ }^{7-9}$ the question addressed here was how do B cells influence the recall response to $L$. major.

Wild-type C57Bl/ 6 and $\mu \mathrm{MT}$ mice were originally obtained from Jackson Laboratories (Bar Harbor, ME) and bred at the Laboratory Animal Resources facility at Colorado State University as previously described. ${ }^{18}$ The maintenance and care of all experimental animals complied with National Institutes of Health guidelines for the humane use of laboratory animals. Female mice (6-8 weeks of age, five per group) were infected with $10^{6}$ L. major promastigotes (LV39, RHO/SU/ 59/P, Neal, or P strain) in one rear foot pad. ${ }^{19}$ Lesion size was monitored over time with vernier calipers (lesion size $=$ infected foot - contralateral uninfected foot).

As shown in Figure 1A, we confirmed that both wild-type and $\mu \mathrm{MT}$ mice were resistant to $L$. major after primary challenge. However, using an enzyme-linked immunosorbent assay technique ${ }^{20}$ to analyze 48-hour supernatants from cultured, L. major-restimulated lesion-draining lymph node cells taken 20 days post-infection, we observed that cells from $\mu$ MT mice produced significantly less IFN- $\gamma$ (approximately half as much; $P=0.01$ ) than did cells from wild-type mice (Table 1). These data are similar to those of others who showed reduced IFN- $\gamma$ production after pathogen challenge in $\mu \mathrm{MT}$ mice. ${ }^{13-15}$ In contrast, we found that production of interleukin-2 (IL-2), IL-4, and IL-10 was not different between the two mouse strains. Interestingly, Brown and Reiner ${ }^{7}$ found no difference in IFN- $\gamma$ mRNA levels between wild-type and $\mu \mathrm{MT}$ mice infected with $L$. major, but they analyzed $\mathrm{CD}^{+}$lesion-draining lymph node cells only, rather than production by all lymph node cells as described here. A study by Harris and others ${ }^{21}$ has shown that some B cells can produce IFN- $\gamma$. Therefore, it is possible that the reduced IFN- $\gamma$ production observed here for $\mu \mathrm{MT}$ mice was due to the lack of B cell-produced IFN- $\gamma$. To examine if a similar phenomenon was occurring in the lesion itself, mRNA levels for IFN- $\gamma$ were measured in lesions from wild-type and $\mu \mathrm{MT}$ mice 21 days post-infection using a reverse transcription-polymerase chain reaction technique as described previously. ${ }^{19}$ The data from three individual animals per group are shown in Table 1 (presented as the relative ratio of mRNA for IFN- $\gamma / \beta$-actin) and indicate that IFN- $\gamma$ mRNA levels were lower by $42 \%$ in $\mu \mathrm{MT}$ mice relative to wild-type mice. This reduction in lesion IFN- $\gamma$ mRNA was approximately the same magnitude as the reduction in IFN- $\gamma$ protein produced by lymph node cells from $\mu \mathrm{MT}$ mice.

After lesion resolution (approximately 70 days), some mice (2-4 per group) were reinfected with $10^{6} \mathrm{~L}$. major in the contralateral uninfected footpad. As shown in Figure 1B, an increase in lesion size indicative of a DTH response was observed in wild-type mice and was typical for secondary exposures to L. major antigens. ${ }^{8}$ The peak of this response occurred on day three after rechallenge, and lesion resolution was complete by approximately day 40 . In contrast, in $\mu \mathrm{MT}$ mice, little or no increase in lesion size was observed after secondary infection, and only small lesions were observed to develop in any of these mice in two separate experiments. 


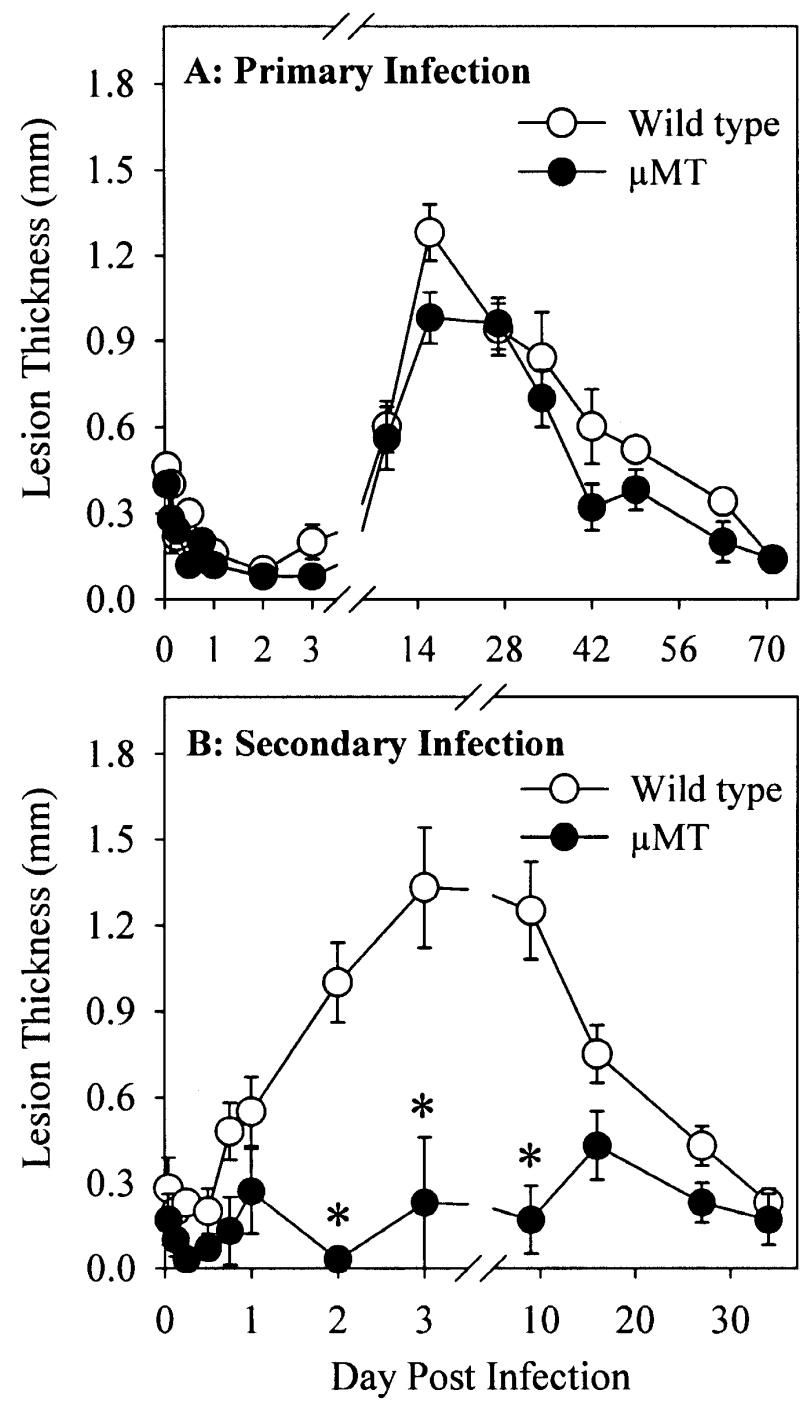

FigurE 1. Requirement of B cells for the expression of delayed type hypersensitivity-like pathology following secondary infection with Leishmania major. Foot lesion size over time is shown for C57B1/6 and $\mu \mathrm{MT}$ mice after primary (A) and secondary (B) infection with $10^{6} \mathrm{~L}$. major. Data represent the mean \pm SEM for $4-5$ animals per group.

Importantly, all lesions resolved in $\mu \mathrm{MT}$ mice over the same time frame as observed for wild-type mice, and no difference in parasite burdens was found. Thus, a lack of B cells did not alter resistance to L. major after secondary challenge. Because DTH responses are associated with IFN- $\gamma$ production in $L$. major-infected animals, ${ }^{3,4,9,16,17}$ IFN- $\gamma$ mRNA levels were measured in lesions taken three days after reinfection with parasites. As shown in Table 1, IFN- $\gamma$ mRNA levels were reduced by $47 \%$ on average in two experiments (the lesions from two animals were pooled per group in each experiment). Clearly, although reduced in the absence of $B$ cells, the amount of IFN- $\gamma$ was sufficient to facilitate resistance in $\mu \mathrm{MT}$ mice. It is unclear, however, if the lack of a DTH response was the result of reduced IFN- $\gamma$ expression or if they are merely coexpressed phenomena. It is interesting that Babai and others ${ }^{8}$ found that in B-1 cell-depleted mice, the DTH response to L. major antigen was unchanged, relative to wild-type mice, nine weeks after primary challenge
TABLE 1

Interferon- $\gamma$ measurements for lesion-draining lymph node cells and foot lesions

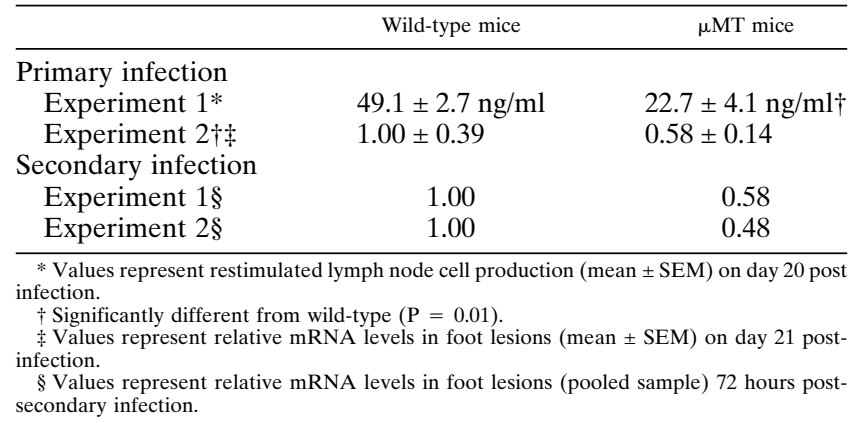

with parasites. In light of their results, the results shown here suggest that classic B cells (those other than B-1 cells), may have a major role in the development of DTH responses to $L$. major in wild-type L. major-resistant mice. Because DTH responses do not correlate with antibody levels to Leishmania ${ }^{10} \mathrm{~B}$ cells are likely to influence DTH responses through a non-antibody-mediated pathway.

Received July 10, 2003. Accepted for publication August 22, 2003.

Financial support: These studies were funded by the National Institutes of Health (grant AI-29955).

Authors' addresses: Gregory K. DeKrey, Department of Biological Sciences, College of Arts and Sciences, University of Northern Colorado, 501 20th Street, Greeley, CO 80639, Telephone: 970-351-2493, Fax: 970-351-2335, E-mail: gregory.dekrey@unco.edu. M. Lamine Mbow, Centocor, Incorporated, Infectious Diseases, 200 Great Valley Parkway, Malvern, PA 19355, Telephone: 610-889-4643, Fax: 610889-4623, E-mail: lmbow@cntus.jnj.com. Claudia I. Brodskyn, Centro de Pesquisa Gonçalo Moniz-FIOCRUZ/Bahia, Rua Valdemar Falcão 121, Salvador, Bahia, Brazil 40295-001, Telephone: 55-71-3568782 Extension 2111, Fax: 55-71-356-2543, E-mail: brodskyn@cpqgm. fiocruz.br. Richard G. Titus, and Jeremy J. Jones, Department of Pathology, College of Veterinary and Biomedical Sciences, Colorado State University, Fort Collins, CO 80523-1671, Telephone: 970-4911607, Fax: 970-491-0603, E-mail: rtitus@colostate.edu.

\section{REFERENCES}

1. Bogdan C, Gessner A, Solbach W, Rollinghoff M, 1996. Invasion, control and persistence of Leishmania parasites. Curr Opin Immunol 8: 517-525.

2. Liew FY, O'Donnell CA, 1993. Immunology of leishmaniasis. Adv Parasitol 32: 161-259.

3. Lohoff M, Gessner A, Bogdan C, Röllinghoff M, 1998. The Th1/ Th2 paradigm and experimental murine leishmaniasis. Int Arch Allergy Immunol 115: 191-202.

4. Reiner SL, Locksley RM, 1995. The regulation of immunity to Leishmania major. Annu Rev Immunol 13: 151-177.

5. Solbach W, Laskay T, 2000. The host response to Leishmania infection. Adv Immunol 74: 275-317.

6. Scott P, Natovitz P, Sher A, 1986. B lymphocytes are required for the generation of $\mathrm{T}$ cells that mediate healing of cutaneous leishmaniasis. J Immunol 137: 1017-1021.

7. Brown DR, Reiner SL, 1999. Polarized helper-T-cell responses against Leishmania major in the absence of B cells. Infect Immun 67: 266-270.

8. Babai B, Louzir H, Cazenave PA, Dellagi K, 1999. Depletion of peritoneal CD5+ B cells has no effect on the course of Leishmania major infection in susceptible and resistant mice. Clin Exp Immunol 117: 123-129.

9. Sacks DL, Scott PA, Asofsky R, Sher A, 1984. Cutaneous leishmaniasis in anti-IgM-treated mice: enhanced resistance due to 
functional depletion of a B cell-dependent T cell involved in the suppressor pathway. J Immunol 132: 2072-2077.

10. Hale C, Howard JG, 1981. Immunological regulation of experimental cutaneous leishmaniasis. 2. Studies with Biozzi high and low responder lines of mice. Parasite Immunol 3: 45-55.

11. Olobo JO, Handman E, Curtis JM, Mitchell GF, 1980. Antibodies to Leishmania tropica promastigotes during infection in mice of various genotypes. Aust J Exp Biol Med Sci 58: 595601.

12. Su H, Feilzer K, Caldwell HD, Morrison RP, 1997. Chlamydia trachomatis genital tract infection of antibody-deficient gene knockout mice. Infect Immun 65: 1993-1999.

13. Yang DM, Rogers MV, Liew FY, 1991. Identification and characterization of host-protective T-cell epitopes of a major surface glycoprotein (pg63) from Leishmania major. Immunology 72: 3-9.

14. Eperon S, Bronnimann K, Hemphill A, Gottstein B, 1999. Susceptibility of B-cell deficient C57Bl/6 ( $\mu \mathrm{MT})$ mice to Neospora caninum infection. Parasite Immunol 21: 225-236.

15. Matsuzaki G, Vordermeier HM, Hashimoto A, Nomoto K, Ivanyi J, 1999. The role of B cells in the establishment of T cell response in mice infected with an intracellular bacteria, Listeria monocytogenes. Cell Immunol 194: 178-185.
16. Howard JG, Hale C, Liew FY, 1980. Immunological regulation of experimental leishmaniasis. III. Nature and significance of specific suppression of cell-mediated immunity in mice highly susceptible to Leishmania tropica. J Exp Med 152: 594-607.

17. Howard JG, Hale C, Liew FY, 1981. Immunological regulation of experimental cutaneous leishmaniasis. IV. Prophylactic effect of sublethal irradiation as a result of abrogation of suppressor $\mathrm{T}$ cell generation in mice genetically susceptible to Leishmania tropica. J Exp Med 153: 557-568.

18. DeKrey GK, Titus RG, 1999. A method for the isolation and analysis of leucocytic cells from leishmanial ear lesions in mice. J Immunol Methods 228: 1-11.

19. Titus RG, DeKrey GK, Morris RV, Suares MBP, 2001. Interleukin-6-deficiency influences cytokine expression in susceptible BALB mice infected with Leishmania major but does not alter the outcome of disease. Infect Immun 69: 5189-5192.

20. Soares MBP, David JR, Titus RG, 1997. An in vitro model for infection with Leishmania major that mimics the immune response in mice. Infect Immun 65: 2837-2845.

21. Harris DP, Haynes L, Sayles PC, Duso DK, Eaton SM, Lepak NM, Johnson LL, Swain SL, Lund FE, 2000. Reciprocal regulation of polarized cytokine production by effector $\mathrm{B}$ and $\mathrm{T}$ cells. Nature Immunol 1: 475-482. 